\title{
Peptides and Peptidomics: A Tool with Potential in Control of Plant Viral Diseases
}

\author{
José Silvestre Mendoza-Figueroa1, Manuel Soriano-García1*, Laura Beatriz Valle-Castillo², \\ Jesús Méndez-Lozano² \\ ${ }^{1}$ Instituto de Química, Universidad Nacional Autónoma de México, Ciudad Universitaria, Coyoacán, Mexico City, \\ Mexico \\ ${ }^{2}$ Instituto Politécnico Nacional, CIIDIR Unidad Sinaloa, Guasave, Mexico \\ Email: soriano@unam.mx
}

Received 25 April 2014; revised 28 May 2014; accepted 2 July 2014

Copyright $@ 2014$ by authors and Scientific Research Publishing Inc.

This work is licensed under the Creative Commons Attribution International License (CC BY).

http://creativecommons.org/licenses/by/4.0/

(c) $\underset{\mathrm{EY}}{\mathrm{EP}}$ Open Access

\begin{abstract}
Plant viruses are the most infectious agents in commercially important crops worldwide. Plant viral diseases are important because both decreased yielding and quality of fruits, flowers or vegetables lead to million-dollar losses in production. At present there are no reports which suggest a direct control of plant virus. A new strategy for plant virus control has been raised since 13 years ago-the use of peptides. Peptides could offer a direct interaction by affinity selection against viral proteins involved in infection cycle, like capsid or movement protein (e.g.) and affect viral replication. Peptidomics, as a new tool to study peptides, led us screening and selecting the best peptide with antiviral activity, and re-designing it to enhance the biological effect as well as the potential of bioactivity of those peptides secreted by microbes present in soil. In this paper we review current aspects in the use of peptides and peptidomics as a strategy to study new methods that lead a direct control against plant viral diseases.
\end{abstract}

\section{Keywords}

Peptidomics, Plant Virus, Peptides, Peptaiboles, Mass Spectrometry, Aptamers

\section{Introduction}

Plant diseases are known since men started cropping in ancient times, but concepts about them have been passed through large and continued evolutionary process change in more than 20 centuries. Greeks philosophers as Teofrasto, talked about disease in cultures and they supposed possible origin and some treatments [1]. Commer-

${ }^{*}$ Corresponding author.

How to cite this paper: Mendoza-Figueroa, J.S., Soriano-García, M., Valle-Castillo, L.B. and Méndez-Lozano, J. (2014) Peptides and Peptidomics: A Tool with Potential in Control of Plant Viral Diseases. Advances in Microbiology, 4, $539-548$. 
cially important crops such as vegetables, ornamental plants, grasses and cereals are not free to get infections which decrease their yielding and production. One of the main etiologies in plant diseases is caused by viruses; these agents are responsible for high lost in yielding and quality in crops worldwide. These losses are variable year to year, and have been in function of weather, crop management, chemical and cultural control of vectors (insects) and weeds, and in some case reached $100 \%$ losses [2].

Pathogens plant viruses are small pathogens and depend on the replication host machinery to replicate and generate progeny [3]. Plant viruses are classified based on features of nomenclature and taxonomy described by International Committee for Taxonomy of Viruses (ICTV) [4]. Currently, there are 2828 species of plant viruses that belong to 455 genera [5].

Last report by MicrobiologyBytes in collaboration with the Molecular Plant Pathology Association described the "Top Ten" of plant virus and highlighted those viruses with more importance in point of view of scientist or economy interest; this ranking is described in Table 1.

Frequency of these infections has been increased in most agricultural areas worldwide, pointing the theme of the more important affection in crops. To get control in any disease, it is relevant to know the etiological agent based on identification through miscellaneous laboratory methods, which leads us searching for handling and control of disease. Accurate diagnosis of the viral agent is a determinate factor in developing control alternatives [6].

A strategy to control plant virus is the use of plant resistance genes (R) to viral infection, natural or modified by genetic engineering. If there are $\mathrm{R}$ genes over expressed in natural way, these could come into other cultures by techniques like conventional breeding. Although genetic engineering offers unlimited chances to get virus-resistance crops, its application to large scale has generated disgust for researches, government and people [3]. Genetics treatments, based on the use of resistant strains, seem ideal to control these disease, as option to decrease use of pesticides in crops. But, many kinds of reactions can be observed in a short or large time; partial resistance, tolerance and immunity to disease, are some examples. Two alternatives are proposed along this review to get news strategies in plant virus control: 1) the use of arbuscular mycorrhizal fungi, considered as a natural defense in plant besides enhancing yield and resistance [7]; 2) the use of small molecules such as peptides with high specificity to viral target, and block in direct way of the process of replication or viral assembly.

The aim of this review is to collect and disclose current strategies to develop plant viral control using peptides, based on techniques of peptidomics like tool for developing studies of direct molecule-molecule interaction.

Table 1. Ranking with principal plant virus in regard to scientist and economy effect (data from MicrobiologyBytes).

\begin{tabular}{|c|c|c|}
\hline Specie & Genus & Host range \\
\hline Tobacco mosaic virus (TMV) & Tobamovirus & Tobacco, tomato, and other Solanaceae \\
\hline Tomato spotted wilt virus (TSWV) & Tospovirus & $\begin{array}{l}\text { Over } 1000 \text { species in } 85 \text { families, including many } \\
\text { vegetables, peanuts and tobacco }\end{array}$ \\
\hline Tomato yellow leaf curl virus (TYLCV) & Begomovirus & Mostly tomato and other Solanaceae \\
\hline Cucumber mosaic virus (CMV) & Cucumuvirus & $\begin{array}{l}\text { Cucumbers, squash, melons, peppers, beans, } \\
\text { tomatoes, carrots, celery, lettuce, spinach, various } \\
\text { weeds and many ornamental plants }\end{array}$ \\
\hline Potato virus Y (PVY) & Potyvirus & $\begin{array}{l}\text { Important crops such as pepper, potato, tobacco, } \\
\text { tomato, some ornamental plants and many weeds. }\end{array}$ \\
\hline Cauliflower mosaic virus (CaMV) & Caulimovirus & $\begin{array}{l}\text { Arabidopsis thaliana, Brassica spp., Raphanus spp. } \\
\text { and other species of Brassicaceae and Resedaceae }\end{array}$ \\
\hline African cassava mosaic virus (ACMV) & Begomovirus & Cassava, Nicotiana and Datura \\
\hline Plum pox virus (PPV) & Potyvirus & $\begin{array}{l}\text { Stone fruits including peaches, apricots, plums, } \\
\text { nectarines, almonds and sweet and sour cherries }\end{array}$ \\
\hline Brome mosaic virus (BMV) & Bromovirus & $\begin{array}{l}\text { Mainly monocots such as barley and others in the } \\
\text { grass family }\end{array}$ \\
\hline Potato virus $X$ (PVX) & Potexvirus & Potato and other Solanaceae \\
\hline
\end{tabular}




\section{Peptidomics a Tool for Plant Virus Control}

\subsection{Bioactive Peptide Libraries}

Several strategies had been described to get peptides in function microbial agent's control, between them, peptides with target to bacterial membrane [8] or antifungal activity [9]. In some cases those molecules had gotten from specificity selection assays based in directly interaction between molecules as well as modification of bioactive peptides and de novo design reported previously in data base like PhytAMP [10]-[13], using combinatory chemistry and computational chemistry like tools to enhance the antimicrobial activity and develop and chose new peptides with a best biological activity [10]. Because, plant virus are particles formed of proteins like capsid (CP), nucleoproteins (N) and movement proteins (MP), we may think in the possibility to produced synthetic peptides or peptides derivate from hydrolysis of big proteins, which target, based via interaction peptide-viral protein or peptide-viral peptide assays, and propose the potential biological effect based on this interaction affinity system [12]. Those studies can use peptide libraries derivate of protein hydrolysis from plants or functional foods like casein (e.g.) [14]. Peptides libraries from plant proteins with antiviral activity is not explorer option yet, but peptides libraries from casein derivate has demonstrated that are able to decrease infection and symptoms in farms of salmons for IHNV (Infectious hematopoietic necrosis virus) [15]. Thus, a peptide derivate from FGF (Fibroblast Growth Factor) showed antiviral activity against an influenza virus (H5N1) [16]. Thus, we propose that peptides from protein plant hydrolysis could be a possible way to get peptide libraries with possible anti plant virus activities.

The biopanning assay (selection through interaction) is performed fixing the target molecule (viral protein or viral peptide, viral antigens) on a solid surface; it could be performed in solution (like immunoprecipitation). The peptide libraries, either synthetics, derivate from protein hydrolysis or phagepeptides, after, they will be add onto viral antigen fixed on the surface of reaction system (microplate e.g.), with the aim to let a random molecular interaction, in this way, only peptides with the best affinity to target, will allow interacting. The interaction time and incubation condition for this assay is at least 30 minutes to 1 hour in room temperature [12] [16]-[18]. After incubation time, is necessary to remove the peptides which did not interact or did not bind to the target. Binding peptides are eluted (if we performed the beads to collect the complex peptide-target, likewise immunoprecipitation). Eluted peptides should be analyzed using electrophoresis methods like Two-Dimensional gels (2D gels), or purified using chromatographic methods [12]. 2D gels allow separating in two parameters the complex mix or analyzed pure peptides or proteins, these parameters are 1) mass (Molecular Weight, MW) and 2) charge. Each band in the gel represent a peptide in the mix with itself features such as mass and charge. We could remove each band and confirm the MW by Mass Spectrometry (MS) method. Furthermore, MS can confirm whether peptide contain an S-S bond. In the study of peptides via MS, principal ionization method is MALDI and analyzed with TOF [12] [19]-[21]. MALDI (Matrix Assisted Laser Disruption Ionization) as well as ESI (Electro Spray Ionization) there are soft ionization non-molecule destructive methods, which let know the properties of peptides and proteins such as MW, pure, and S-S association [22] [23]. The MALDI-TOF MS, is a tool to know the MW of peptide selected against target. We could purified the mix of peptides in HPLC (these kind of peptides are not susceptible to degradation in high pressure indeed there are linear, small circular in Phagepeptides (no more 15 amino acids) or derivate from hydrolysis) coupled ESI MS/MS to get purified peptide and know the MW. Furthermore, we could know sequence de novo via trypsin digestion of each purified peptide or band in 2D gel, using CID MS/MS or get the fingerprint MALDI TOF/TOF [23]. We could analyze and purified via LC MS, the mix of selected peptides without passing 2D gels like shows in the general process in Figure 1.

Once peptides sequences are known, the follow interest is to generate a 3D structure model of the peptide, this approach, will let us theoretical studies of the interaction dynamics of peptide-target and know the docking energy of the system in this interaction. These studies will help us to re-select peptides with the best probability of biological activity [10]. 3D peptide structure is performed by Molecular mechanics or Markov alphabet, first model is a singular mechanics balls-spring system using the real conformation state of the atoms in the peptide [24] [25]. Markov alphabet is a alternative to propose a peptide structure using software which are based in modeling by comparison of the original peptide sequence with a algorithm structural alphabet formed by 27 structural letters [26]. There are software's like PEP-FOLD who modeling peptides with this method (http://bioserv.rpbs.univ-paris-diderot.fr/PEP-FOLD/). Spectroscopic techniques like NMR is the way to know the real 3D structure of the peptide, lineal or cyclic [20]. Last method above mentioned, allows get more information about theoretical interactions between two molecules and predicts bioactivity for example in peptides. 


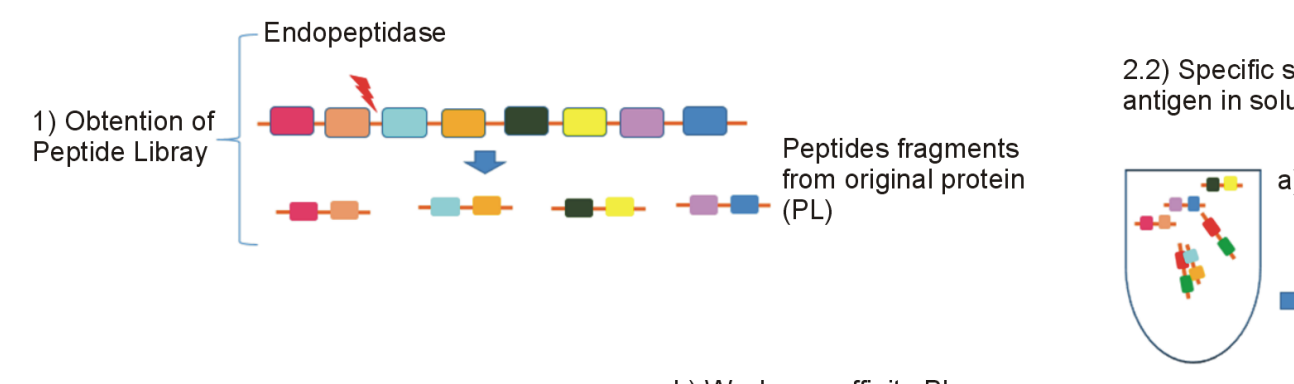

2.2) Specific selection with

from original protein

a) Interaction

b) Add Antibody anti Antigenan colect the

a) Interaction

b) Wash non affinity PL

2.1.) Specific selection In Surface (Antigen fix)

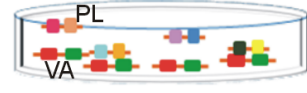

c.1) $\mathrm{Re}$ selection
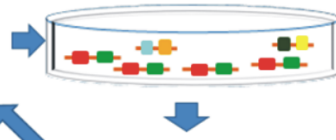

c) Elution affinity $\mathrm{PL}$

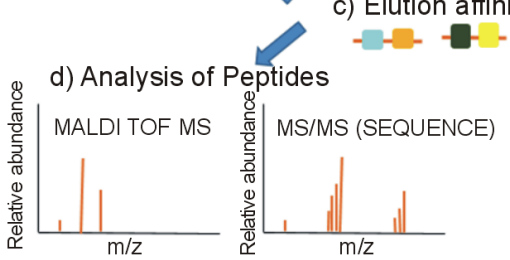

c) Elution affinity $P L$ of complex

complex VA-PL

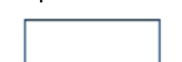

\section{.}


Table 2. Summary principal importance virus's which produce local infections (superficial in leaves and roots) and systemic infection (sieve elements).

\begin{tabular}{|c|c|c|}
\hline Replication Site & Genera & Virus \\
\hline Superficial (Leaves, Roots) & $\begin{array}{l}\text { Cilevirus } \\
\text { Tobravirus } \\
\text { Tospovirus }\end{array}$ & $\begin{array}{c}\text { CiLV-Ci (Citrus leprosis virus-Citplasmic), } \\
\text { TRV (Tobaco rattle virus), PepRSV (Pepper ringspot virus), } \\
\text { INSV (Impatiens necrotic spot virus) }\end{array}$ \\
\hline Phloem (SE) & $\begin{array}{l}\text { Begomovirus } \\
\text { Cucumovirus } \\
\text { Closterovirus } \\
\text { Tobamovirus }\end{array}$ & $\begin{array}{c}\text { TYLCV (Tomato yellow leaf curl virus), } \\
\text { CMV (Cucumbermosaic virus), } \\
\text { CTV (Citrus tristeza virus), } \\
\text { TMV (Tobacomosaic virus), ToMV (Tomatomosaic virus) }\end{array}$ \\
\hline
\end{tabular}

\section{In Vivo Selection of Peptides Libraries against Viral Proteins}

In regard to get treatments against systemic viral replication, some strategies had been developed; The form to achieve this aim, is through in plant synthesis of peptides (transgenic plants) derivate from antigenic regions of viral proteins such as CP, MP and Rep [31], in this way, plant will turn on the immune system response against virus, like MAMP's trigger immunity [32] [39]. Another way to achieve this goal is to develop a screening in live system of peptide libraries which interacts and bind with some viral target, commonly using a yeast system (yeast two-hybrid interaction assay [40]-[42]). The basis for this technique is induce the direct interaction through peptide target (viral target) attachment region to DNA (DBD, DNA binding domain) in promoter of reporter selection gen, with, different peptides attachments (each peptide in a plasmid) to AD (Activation Domain in RNA polymerase binding site). In normal conditions this regions interacts and their interaction becomes to up-stream transcription of the gene, see Figure 2. This fact, was used as basis of the method for adding peptides from a libraries to AD region and the targets or viral target in the DBD region, if both sequences are able to interacts, these will conduce to closer the DBD and AD regions to drive transcription of the reporter gene. The transcription of reporter gene, leads up to believe that both sequence, target and peptide, are able to bind and is possible to use like bioactive peptide against target, this kind of peptides are called peptides aptamers [43]. The select peptides are after cloning in plants (transgenic plants).

Reports on peptides aptamers with antiviral activity are based in the interaction of peptides derivates of common binding microdomain in N protein of Tosporvirus (TSWV, TCSV, GRSV, INSV and SYSV) as peptides targets, and a library of peptides derivates from other places in N protein of Tospovirus. Results show antiviral activity in Nicotiana benthamiana transgenic plants, peptides that closers interaction, decrease symptoms and viral RNA [42].

In case of systemic virus, some more important: geminivirus (TYLCV, TGMV), there are reports with peptide aptamers libraries with target to initiator replication proteins (AL1) [40] and Rep [41], these proteins are significant because are essential to starting replication in several virus [44]. Both reports show that using a $N$. benthamiana transgenic model, containing aptamers peptides with previously screening in YTH, decrease the symptom and DNA level (see Figure 3).

Once established the peptides aptamers library with best biological activity, we can carry out computational studies to confirm the biological dynamics of peptide and suggest modification to enhance the antiviral activity. These kinds of peptides are able to control localized and systemic virus infection in plants like above mention. Although the system is required in transgenic plants, there are not more studies in which peptides aptamers shows disturb plant metabolism. Results with experimental crop field studies are not reported, yet.

\section{Antiviral Plant Peptides from Plant-Microbe Interactions}

The best nutritional source in plant is the soil. Is also source of pathogen microbe as fungi, bacterial, nematodes and virus. However, there are some microbe groups which are associated with plant roots or live near plant, this sometimes is an advantage in plant because this microbe group yield antimicrobial compounds against plant pathogens. Especially in plant virus, had been described bacteria such as Pseudomonas chlororaphis O6 and fungus as Trichodermapseudokoningii SMP2, Spedonium (Apiocrea, sexual phase), Boletus sp. [20] [27] [28] [45]. Their populations of these microbes are principally in soil, and can relate with plants [46] [47]. They produce peptides, with difference in generic pathway, and structural, and they plays in Systemic Induced Resistance (SIR), allowing the antiviral response. 
a) Normal Conditions

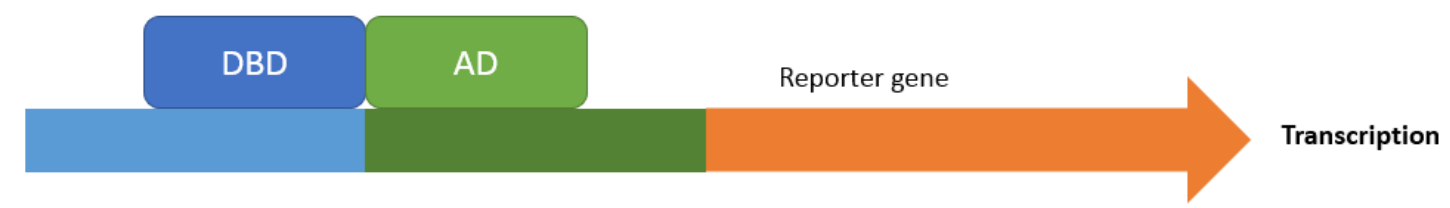

b) Afinity between Target and Peptide library

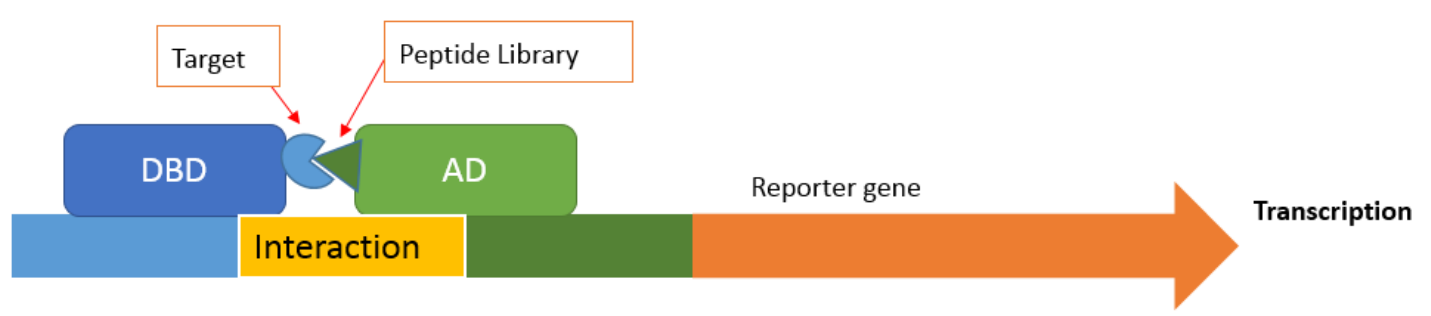

c) Non Afinity between Target and Peptide library

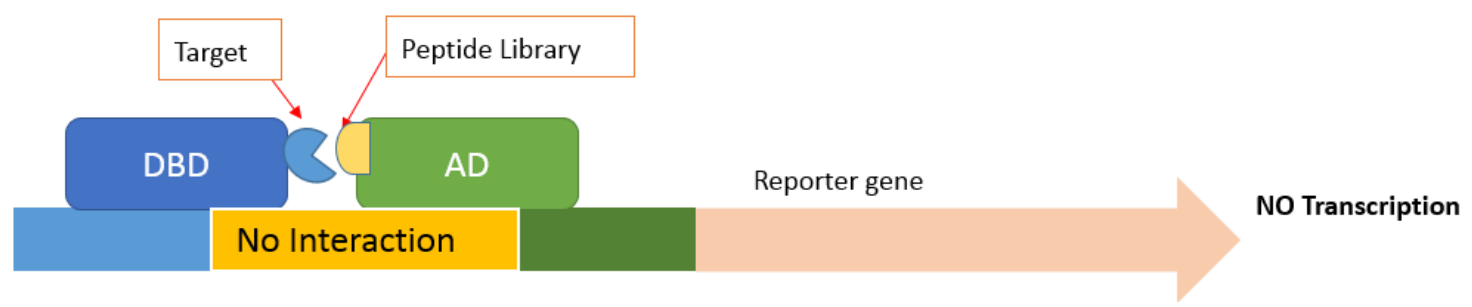

Figure 2. Yeast two-hybrid interaction assay. In normal conditions DBD region and AD are closer to let transcription of gen (a); If viral target coupled to DBD region and peptide from libraries coupled to AD region are able to binding, they closer interaction of DBD-AD and let the transcription of reporter gene (b); If not affinity between target and peptide from library the closer of DBD and AD does not occur, and does not transcription of reporter gene (c). DBD: DNA binding domain, AD: Activation domain.

Experiments shows inoculated plants with $P$. chlororaphis $\mathrm{O6}$ enable the plant develop resistance against Cucumber mosaic virus (CMV) in Nicotianatabaccum [48]. Subsequently Park Y.J. and collaborators, 2012 performed a resistance model with $P$. chlororaphis $\mathrm{O} 6$ in tobacco plants infected with TMV, the goal of these experiments were the purification of the active compound which induce SIR against TMV, researchers found in aqueous extract a cyclic peptide, this molecule consist by 7 amino acids and was analyzed by ESI-Q-TOF MS and NMR to structural studies. Pure peptide called "Peptamine" was assayed in tobacco plants TMV infected, peptide was add to plant through spray on the leaves, results showed antiviral activity likewise model only $P$. chlororaphis in substrate [20].

There are other peptide group comprise by non-proteinogenic amino acids called Peptaibols, they are formed with $\mathrm{N}$ terminal with acetilation and $\mathrm{C}$ terminal amino alcohol, the principal amino acids are $\alpha$-aminoisobutiric (Aib) and Isovaline (Iva). Biological activity has broad spectrum against gram positive bacteria, and fungal [49]. However there are 3 kind of peptaibols with antiviral activity in plants such as 1) Chryospermins B and D, its produced Apiocrea Chrysoperma [45]. 2) Peptavirins A and B, them produced by Spedonium (Apiocreasp 14T). Both groups of pure peptaibols have showed resistance against TMV in tobacco plants [27]. 3) Trichokonins, produced in Trichoderma pseudokoningii SMP2, were purified and tested in tobacco plants infected with TMV, this peptaibol induced the SIR and decrease severe virus infection in concentration of $100 \mathrm{nM}$, it was showing decrease of $60 \%$ in viral RNA, as well as decline in symptoms severity. Other important date in the experiment is the test of Reactive Oxygen Species (ROS) production such as $\mathrm{H}_{2} \mathrm{O}_{2}$ and $\mathrm{O}_{2}^{-}$and phenolic compounds showed enhanced the production as well as the ROS enzymes in tobacco leaves; these dates suggest that peptaibols are peptides which acts like SIR elicitors [28], see Figure 3.

\section{Conclusion}

In our vision of peptidomics, all these peptides mentioned could be a new frontier to search and design new 


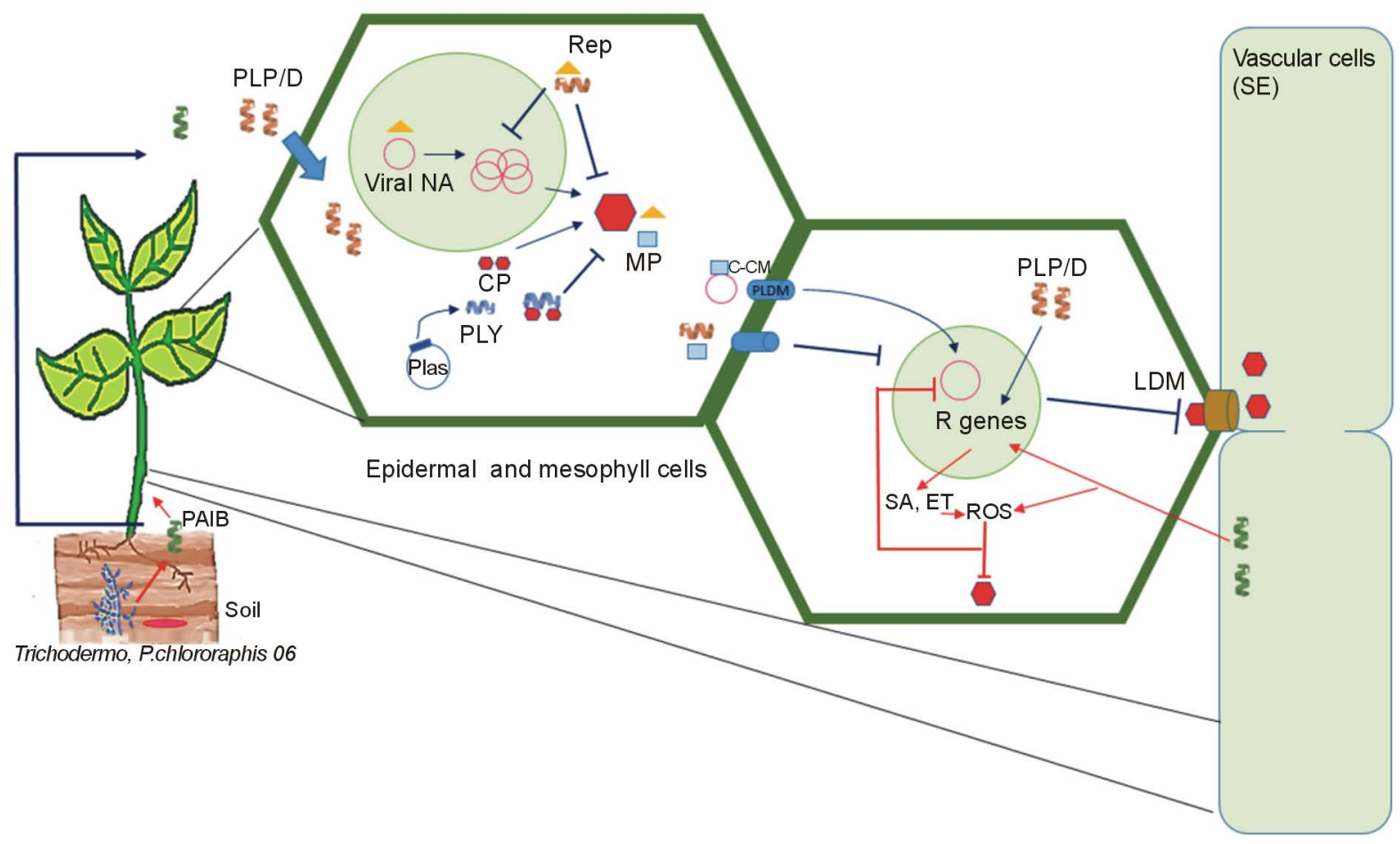

Figure 3. A general scheme of possible antiviral activity mechanism using peptides is shown. Peptides from libraries (PL/D) (derivate from plant proteins, phagedisplay, synthetics) with specific selection against viral targets such Coat Protein (CP), Movement Protein (MP) or Replicase (Rep); are sprayed on leaves and these come into cell, in cell they can bind to specific target and block replication of Viral Nucleic Acid (Viral NA) and block other process such as transcription of other viral proteins, both bind to MP and block the movement of viral nucleic acids and virion into cell-cell (C-CM) through Plasmodesmata (PLDM), having consequently decrease in Long Distal Movement (LDM) and systemic infection. Peptides aptamers (PLY) in transgenic plants (Plas) are able to develop a response likewise described above. In case of peptaibols (PAIB), they are synthesize by fungal as Trichoderma or cyclic peptides by P. chlororaphis $\mathrm{O} 6$ in soil, plant absorbs and in this way will enhance Resistance genes (R genes) and pathways like Salicylic Acid (SA) and Ethylene (ET) consequently enhance of Reactive Oxigen Species (ROS) and phenolic compounds, decrease the synthesis of viral nucleic assay and the systemic virus and localized.

strategies to enhance the protection against virus; tools like MALDI-TOF and computational chemistry are options that allow us to research direct molecular interactions into small molecules with viral particles and to think in a possible direct treatment against plant virus. However studies in crops are not developed yet, it is necessary to motive researches in the study of crop fields and monitor in vivo protection. This work also presents an alternative to the use of transgenic plants, exploring the use of peptide libraries derivates from plant or animal proteins or other sources.

\section{References}

[1] Patiño, M.R., Hernández, P. and Suárez, R. (1981) Sanidad Vegetal. Pueblo y Educación, Ministerio de Educación, Cuba.

[2] Vidales, F.J.A. and Alcantar, R.J.J. (1989) Ataque de la virosis durante la floración y su efecto sobre la producción de melón (Cucumismelo L.). Memories of XVI National Congress of Mexican Plant Pathology Society.

[3] Gergerich, R.C. and Dolja, V.V. (2006) Introduction to Plant Viruses, the Invisible Foe. The Plant Health Instructor.

[4] Hull, R. (2002) Matthews’ Plant Virology. 4th Edition, Academic Press, San Diego.

[5] International Committee on Taxonomy of Viruses (2013) Virus Taxonomy Assignments. http://www.ictvonline.org/virusTaxInfo.asp

[6] González, L.R. and Delgadillo, S.F. (1989) Inclusiones producidas por algunos virus fitopatógenos. Memories of XVI National Congress of Mexican Plant Pathology Society.

[7] Maffei, G., Miozzi, L., Fiorilli, V., Novero, M., Lanfranco, L. and Accotto, G.P. (2013) The Arbuscular Mycorrhizal 
Symbiosis Attenuates Symptom Severity and Reduces Virus Concentration in Tomato Infected by Tomato Yellow Leaf Curl Sardinia Virus (TYLCSV). Mycorrhiza, 24, 179-186. http://dx.doi.org/10.1007/s00572-013-0527-6

[8] Mandal, S.M., Migliolo, L. and Franco, O.L. (2012) The Use of MALDI-TOF-MS and in Silico Studies for Determination of Antimicrobial Peptides' Affinity to Bacterial Cells. Journal of the American Society for Mass Spectrometry, 23, 1939-1948. http://dx.doi.org/10.1007/s13361-012-0453-4

[9] Rivillas-Acevedo, L.A. and Soriano-García, M. (2007) Isolation and Biochemical Characterization of an Antifungal Peptide from Amaranthus hypochondriacus Seeds. Journal of Agricultural and Food Chemistry, 55, 10156-10161. http://dx.doi.org/10.1021/jf072069x

[10] Zeitler, B., Herrera Diaz, A., Dangel, A., Thellmann, M., Meyer, H., et al. (2013) De-Novo Design of Antimicrobial Peptides for Plant Protection. PLoS ONE, 8, e71687. http://dx.doi.org/10.1371/journal.pone.0071687

[11] López-García, B., San Segundo, B. and Coca. M. (2012) Antimicrobial Peptides as a Promising Alternative for Plant Disease Protection. Small Wonders: Peptides for Disease Control, 263-294.

[12] Kool, J., Jonker, N., Irth, H. and Niessen, W.M. (2011) Studying Protein-Protein Affinity and Immobilized LigandProtein Affinity Interactions Using MS-Based Methods. Analytical and Bioanalytical Chemistry, 401, 1109-1125. http://dx.doi.org/10.1007/s00216-011-5207-9

[13] Mooney, C., Haslam, N.J., Pollastri, G. and Shields, D.C. (2012) Towards the Improved Discovery and Design of Functional Peptides: Common Features of Diverse Classes Permit Generalized Prediction of Bioactivity. PLoS ONE, 7, e45012. http://dx.doi.org/10.1371/journal.pone.0045012

[14] Phelan, M., Aherne, A., Richard, J., FitzGerald, R.J. and O’Brien, N.M. (2009) Casein-Derived Bioactive Peptides: Biological Effects, Industrial Uses, Safety Aspects and Regulatory Status. International Dairy Journal, 193, 643-654. http://dx.doi.org/10.1016/j.idairyj.2009.06.001

[15] Rodríguez Saint-Jean, S., De las Heras, A., Carrillo, W., Recio, I., Ortiz-Delgado, J.B., Ramos, M., Gomez-Ruiz, J.A., Sarasquete, C. and Pérez-Prieto, S.I. (2013) Antiviral Activity of Casein and $\alpha_{\mathrm{s} 2}$ Casein Hydrolysates against the Infectious Haematopoietic Necrosis Virus, a Rhabdovirus from Salmonid Fish. Journal of Fish Diseases, 36, 467-481. http://dx.doi.org/10.1111/j.1365-2761.2012.01448.x

[16] Jones, J.C., Elizabeth, A., Turpin, E.A., Bultmann, H., Curtis, R., Brandt, C.R. and Schultz-Cherry, S. (2006) Inhibition of Influenza Virus Infection by a Novel Antiviral Peptide That Targets Viral Attachment to Cells. Journal of Virology, 80, 11960-11967. http://dx.doi.org/10.1128/JVI.01678-06

[17] Arap, M.A. (2005) Phage Display Technology_Applications and Innovations. Genetics and Molecular Biology, 28, 1-9. http://dx.doi.org/10.1590/S1415-47572005000100001

[18] Foster, G., Johansen, E., Hong, Y. and Nagy, P. (2008) Plant Viral Protocols. 2nd Edition, Human Press, New York. http://dx.doi.org/10.1007/978-1-59745-102-4

[19] Panchaud, A., Affolter, M. and Kussmann, M. (2012) Mass Spectrometry for Nutritional Peptidomics: How to Analyze Food Bioactives and Their Health Effects. Journal of Proteomics, 75, 3546-3559. http://dx.doi.org/10.1016/j.jprot.2011.12.022

[20] Park, J.Y., Yang, S.Y., Kim, Y.C., Dang, Q.L., Kim, J.J. and Kim, I.S. (2012) Antiviral Peptide from Pseudomonas chlororaphis O6 against Tobacco Mosaic Virus (TMV). Journal of the Korean Society for Applied Biological Chemistry, 55, 89-94. http://dx.doi.org/10.1007/s13765-012-0015-2

[21] Liao, Y., Alvarado, R., Phinney, B. and Lönnerdal, B. (2011) Proteomic Characterization of Specific Minor Proteins in the Human Milk Casein Fraction. Journal of Proteome Research, 10, 5409-5415.

[22] Kathleen, L., Wei, J. and Siuzdak, G. (2006) Matrix-Assisted Laser Desorption/Ionization Mass Spectrometry in Peptide and Protein Analysis. In: Meyers, R.A., Ed., Peptides and Proteins, Encyclopedia of Analytical Chemistry, 58805894.

[23] Seidler, J., Zinn, N., Boehm, M.E. and Lehmann, W.D. (2010) De Novo Sequencing of Peptides by MS/MS. Proteomics, 10, 634-649. http://dx.doi.org/10.1002/pmic.200900459

[24] Schlick, T. (2010) Molecular Modeling and Simulation. An Interdisciplinary Guide. 2nd Edition, Springer, Berlin. http://dx.doi.org/10.1007/978-1-4419-6351-2

[25] Cramer, C.J. (2004) Essential of Computational Chemistry. Theories and Models. 2nd Edition, Wiley, Hoboken.

[26] Camproux, A.C. and Tufféry, P. (2005) Hidden Markov Model-Derived Structural Alphabet for Proteins: The Learning of Protein Local Shapes Captures Sequence Specificity. Biochimica et Biophysica Acta, 1724, 394-403. http://dx.doi.org/10.1016/j.bbagen.2005.05.019

[27] Yeo, W.H., Yun, B.S., Kim, Y.S., Lee, S.J., Yoo, I.D., Kim, K.S., Park, E.K., Lee, J.C. and Kim, Y.H. (2002) Antiviral, Antimicrobial, and Cytotoxic Properties of Peptavirins A and B Produced by Apiocrea sp. 14T. The Plant Pathology Journal, 18, 18-22. http://dx.doi.org/10.5423/PPJ.2002.18.1.018 
[28] Luo, Y., Zhang, D.D., Dong, X.W., Zhao, P.B., Chen, L.L., Song, X.Y., Wang, X.J., Chen, X.L., Shi, M. and Zhang, Y.Z. (2010) Antimicrobial Peptaibols Induce Defense Responses and Systemic Resistance in Tobacco against Tobacco Mosaic Virus. FEMS Microbiology Letters, 313, 120-126. http://dx.doi.org/10.1111/j.1574-6968.2010.02135.X

[29] Locali-Fabris, E.C., Freitas-Astúa, J., Souza, A.A., Takita, M.A., Astúa-Monge, G., Antonioli-Luizon, R., Rodrigues, V., Targon, M.L. and Machado, M.A. (2006) Complete Nucleotide Sequence, Genomic Organization and Phylogenetic Analysis of Citrus Leprosis Virus Cytoplasmic Type. Journal of General Virology, 87, 2721-2199. http://dx.doi.org/10.1099/vir.0.82038-0

[30] Manhy, B.W. and Van Regenmortel, H.V. (2010) Desk Encyclopedia of Plant and Fungal Virology. Academic Press, New York.

[31] Sastry, K.S. (2013) Plant Virus and Viroid Diseases in the Tropics, Vol. 2: Epidemiology and Management. Springer, Berlin.

[32] Mandadi, K.K. and Cholthof, K.B.G. (2013) Plant Immune Responses against Viruses: How Does a Virus Cause Disease? The Plant Cell, 25, 1489-1505. http://dx.doi.org/10.1105/tpc.113.111658

[33] Yamaguchi, Y. and Huffaker, A. (2011) Endogenous Peptide Elicitors in Higher Plants. Current Opinion in Plant Biology, 14, 351-357. http://dx.doi.org/10.1016/j.pbi.2011.05.001

[34] Trejo-Saavedra, D.L., García-Neria, M.A. and Rivera-Bustamante, R.F. (2013) Benzothiadiazole (BTH) Induces Resistance to Pepper golden mosaic virus (PepGMV) in Pepper (Capsicum annuum L.). Biological Research, 46, 333340. http://dx.doi.org/10.4067/S0716-97602013000400004

[35] Chen, T.Z., Lv, Y.D., Zhao, T.M., Li, N., Yang, Y.W., Yu, W.G., He, X., Liu, T.L. and Zhang, B.L. (2013) Comparative Transcriptome Profiling of a Resistant vs. Susceptible Tomato (Solanum lycopersicum) Cultivar in Response to Infection by Tomato Yellow Leaf Curl Virus. PLoS ONE, 8, e80816. http://dx.doi.org/10.1371/journal.pone.0080816

[36] Mase, K., Ishihama, N., Mori, H., Takahashi, H., Kaminaka, H., Kodama, M. and Yoshioka, H. (2013) Ethylene-Responsive AP2/ERF Transcription Factor MACD1 Participates in Phytotoxin-Triggered Programmed Cell Death. Molecular Plant-Microbe Interactions, 26, 868-879. http://dx.doi.org/10.1094/MPMI-10-12-0253-R

[37] Hanley-Bowdoin, L., Bejarano, E.R., Robertson, D. and Mansoor, S. (2013) Geminiviruses: Masters at Redirecting and Reprogramming Plant Processes. Nature Reviews Microbiology, 11,777-788. http://dx.doi.org/10.1038/nrmicro3117

[38] Ghanim, M., Brumin, M. and Popovski, S. (2009) A Simple, Rapid and Inexpensive Method for Localization of Tomato Yellow Leaf Curl Virus and Potato Leafroll Virus in Plant and Insect Vectors. Journal of Virological Methods, 159, 311-314.

[39] Zvereva, A.S. and Pooggin, M.M. (2012) Silencing and Innate Immunity in Plant Defense against Viral and Non-Viral Pathogens. Viruses, 4, 2578-2597. http://dx.doi.org/10.3390/v4112578

[40] Lopez-Ochoa, L., Ramirez-Prado, J. and Hanley-Bowdoin, L. (2006) Peptide Aptamers That Bind to a Geminivirus Replication Protein Interfere with Viral Replication in Plant Cells. Journal of Virology, 80, 5841-5853. http://dx.doi.org/10.1128/JVI.02698-05

[41] Reyes, M.I., Nash, T.E., Dallas, M.M., Ascencio-Ibáñez, J.T. and Hanley-Bowdoin, L. (2013) Peptide Aptamers That Bind to Geminivirus Replication Proteins Confer a Resistance Phenotype to Tomato Yellow Leaf Curl Virus and Tomato Mottle Virus Infection in Tomato. Journal of Virology, 87, 9691-9706. http://dx.doi.org/10.1128/JVI.01095-13

[42] Rudolph, C., Schreier, P.H. and Uhrig, J.F. (2003) Peptide-Mediated Broad-Spectrum Plant Resistance to Tospoviruses. Proceedings of the National Academy of Sciences of the United States of America, 100, 4429-4434.

[43] Mascini, M., Palchetti, I. and Tombelli, S. (2012) Nucleic Acid and Peptide Aptamers: Fundamentals and Bioanalytical Aspects. Angewandte Chemie International Edition, 51, 1316-1332. http://dx.doi.org/10.1002/anie.201006630

[44] Campos Olivas, R., Louis, J.M., Clerot, D., Gronenborn, B. and Gronenborn, A.M. (2002) The Structure of a Replication Initiator Unites Diverse Aspects of Nucleic Acid Metabolism. Proceedings of the National Academy of Sciences of the United States of America, 99, 1310-1315.

[45] Kim, Y.H., Yeo, W.H., Kim, Y.S., Chae, S.Y. and Kim, K.S. (2000) Antiviral Activity of Antibiotic Peptaibols, Chrysospermins B and D, Produced by Apiocreasp. 14T against TMV Infection. Journal of Microbiology and Biotechnology, 10, 522-528.

[46] Han, S.H., Lee, S.J., Moon, J.H., Yang, K.Y., Cho, B.H., Kim, K.Y., Kim, Y.W., Lee, M.C., Anderson, A.J. and Kim, Y.C. (2006) GacS-Dependent Production of 2R, 3R-Butanediol by Pseudomonas chlororaphis O6 Is a Major Determinants for Eliciting Systemic Resistance against Erwinia carotovora but Not against Pseudomonas syringae pv. tabaci in Tobacco. Molecular Plant-Microbe Interactions, 19, 924-930. http://dx.doi.org/10.1094/MPMI-19-0924

[47] Kang, B.R., Han, S.H., Zdor, R.E., Anderson, A.J., Spensor, M., Yang, K.Y., Kim, Y.H., Lee, M.C., Cho, B.H. and Kim, Y.C. (2007) Inhibition of Seed Germination and Induction of Systemic Disease Resistance by Pseudomonas chlororaphis O6 Require Phenazine Production Regulated by the Global Regulator, GacS. Journal of Microbiology 
and Biotechnology, 17, 586-593.

[48] Ryu, C., Kang, B.R., Han, S.H., Cho, S.M., Kloepper, J.W., Anderson, A.J. and Kim, Y.C. (2007) Tobacco Cultivars Vary in Induction of Systemic Resistance against Cucumber mosaic virus and Growth Promotion by Pseudomonas chlororaphis $\mathrm{O} 6$ and Its gacS Mutant. European Journal of Plant Pathology, 119, 383-390. http://dx.doi.org/10.1007/s10658-007-9168-y

[49] Howell, C.R. (2003) Mechanisms Employed by Trichoderma Species in the Biological Control of Plant Diseases: The History and Evolution of Current Concepts. Plant Disease, 87, 4-10. http://dx.doi.org/10.1094/PDIS.2003.87.1.4 
Scientific Research Publishing (SCIRP) is one of the largest Open Access journal publishers. It is currently publishing more than 200 open access, online, peer-reviewed journals covering a wide range of academic disciplines. SCIRP serves the worldwide academic communities and contributes to the progress and application of science with its publication.

Other selected journals from SCIRP are listed as below. Submit your manuscript to us via either submit@scirp.org or Online Submission Portal.
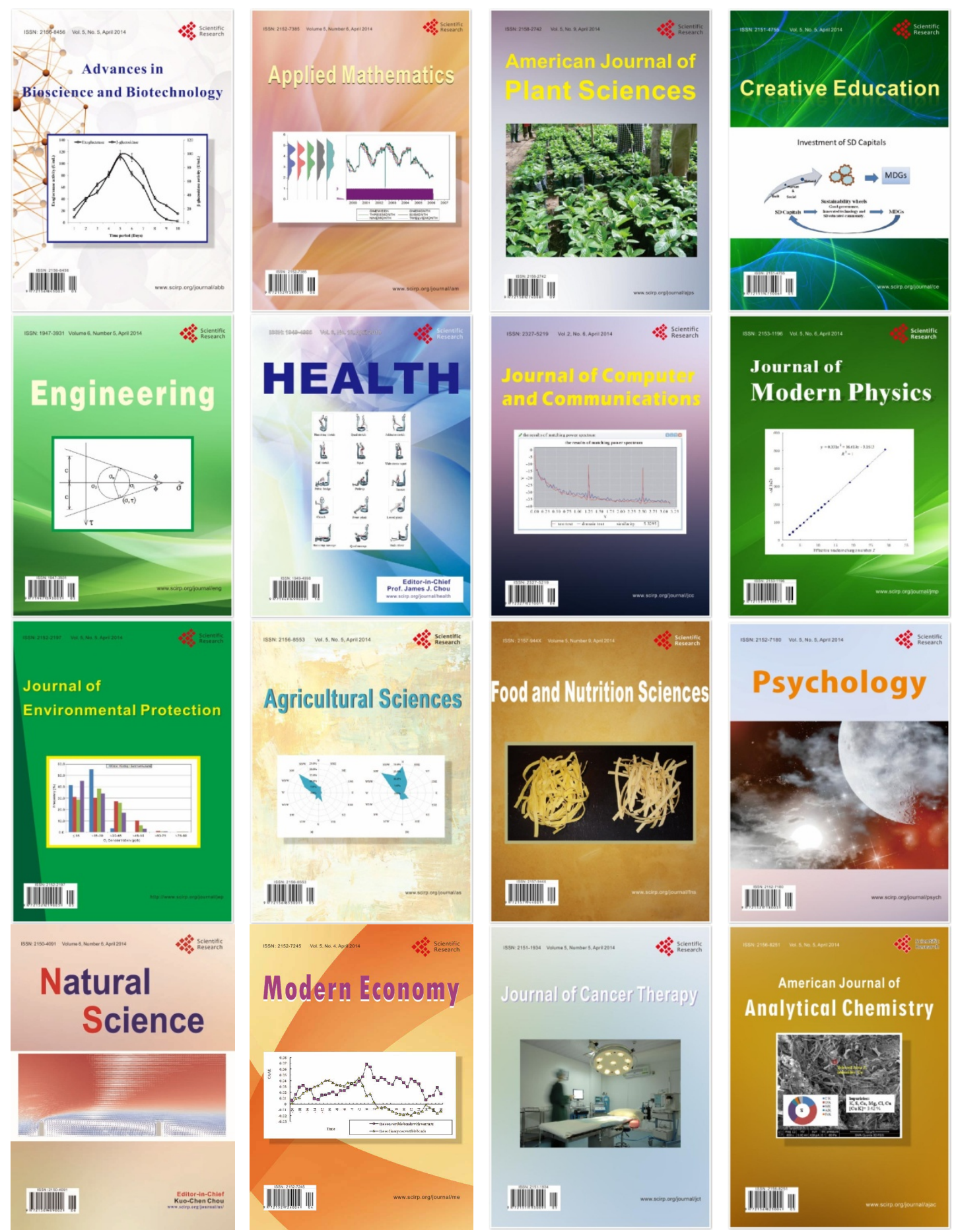